\title{
The Impact of the Post-War Baby-Boom in Finland
}

By RONALD WIMAN

University of Helsinki

Department of Sociology

The problem of population pressure against existing resources is the main concern in the world of today. In the industrialized countries resources have been increasing much faster than population. Behind this general trend there have, however, emerged some bottlenecks in some sectors of society, due to the fast changes in the regional distribution of the population after World War II and, on the other hand, due to the changes of population structure caused by the sharp rise of natality after the war. This flood of new members in the society has now gone through the education process and found its place on the labor market. In this paper we try to trace some of the adjustment problems of the Finnish society when it faced the fast changes of numbers of people in certain age groups, when the "Baby Boom» passed different stages of its life cycle.

\section{The societal relevance of the Baby Boom}

The term "Baby Boom» is a conventional slogan to refer to the sharp rise of the birth rate after World War II. Before the War there had been a Bust», which has often been attributed to the Great Depression of the thirties. This economic hardship was one major reason to cause postponement of marriages and births (see. e.g. Easterlin 1968). The turning point in Finland was the year 1933, when the crude birth rate was down to 18.4. After that the birth rate showed an upward trend until the beginning of the "Winter War", which resulted in an unprecedented drop of the birth rate in 1940. But it rose again more sharply than ever after the war was ended. The continuation of the war in 1941 caused an even sharper drop in the birth rate in 1942. After this the number of births started »booming». The peak of the Baby Boom was in the year 1947 , when more than 108,000 babies were born and the birth rate was 28 per thousand. The post-war cohorts were on average $41 \%$ larger than those during the end of the 'thirties. Since then the sizes of the cohorts have been declining, with two minor exceptions, the years 1952 and 1962 . The birth 
rate already dropped below the 1942 level at the end of the sixties, and the cohorts born in 1971-73 were even smaller than the war-cohort 1942.

In figure 1 the development of the crude birth rates of the USA and Sweden are also presented. In Finland the changes in numbers have been proportionally larger than in these two examples and have thus required more flexibility from the society when the Boom has passed through it. There have also been additional problems which derive from the differential fertility on the regional dimension. In 1960 the proportion of the peak cohorts $1945-50$ was in Lapland still $11.5 \%$ larger than in the country as a whole, and $35 \%$ larger than in the most industrialized part of Finland, the province of Uusimaa. Also in the rural municipalities the proportion of the Boom cohorts was $24 \%$ higher than in the cities and towns. Thus the problems which were created as a consequence of the Boom have been harder in the less-developed parts of Finland, where the recources and alternatives were also more scarce than in the country as a whole.

In the life-cycle of a cohort there are certain stages which are especially relevant in terms of the allocation of societal resources. In general the costs of the cohort exceed the product until the cohort enters the labor market and then again when it retires. ${ }^{1}$

The »costs» of a cohort before it enters the labor force can be considered as investment in the value of shuman capital» (Becker 1975). The »deeper» these investments are, the higher, will in general be the productivity of the cohort when it enters the labor force. ${ }^{2}$ However, when the Boom caused a fast increase of numbers of people going through society, a large share of the net investments in some sectors were demographic in nature, there were heavy investments needed to keep the resources per head at the pre-Boom level and a smaller share was left to the aspirations of increasing the quality of the services measured by resources per head. In the following, the demographic needs and emerging problems due to the Baby Boom are examined more closely in respect to two stages of its life-cycle, education and the labor market.

\section{The bottle-necks in education}

The peak entered the primary schools in 1954. The population of compulsory

1 For quantitative estimates consult Sauvy 1966, 250 and Denton \& Spencer 1975.

2 The investments in the welfare and squality" of the population do not pay off immediately and are thus competing for the resources with the immediately-productive sectors. Those investments allocated to the productive sectors can also be divided between those of »widening» type, i.e. which are needed to provide the tools and machines for the expanding labor force, and those which increase capital per head. Also in this case the former is "demographic» in its nature (See Coale \& Hoover, 1958, chap. 17 and $\gg$ Population policies...» 1974, 28) 
Figure 1. Crude birth rate in Finland, USA and Sweden in 1930-74.

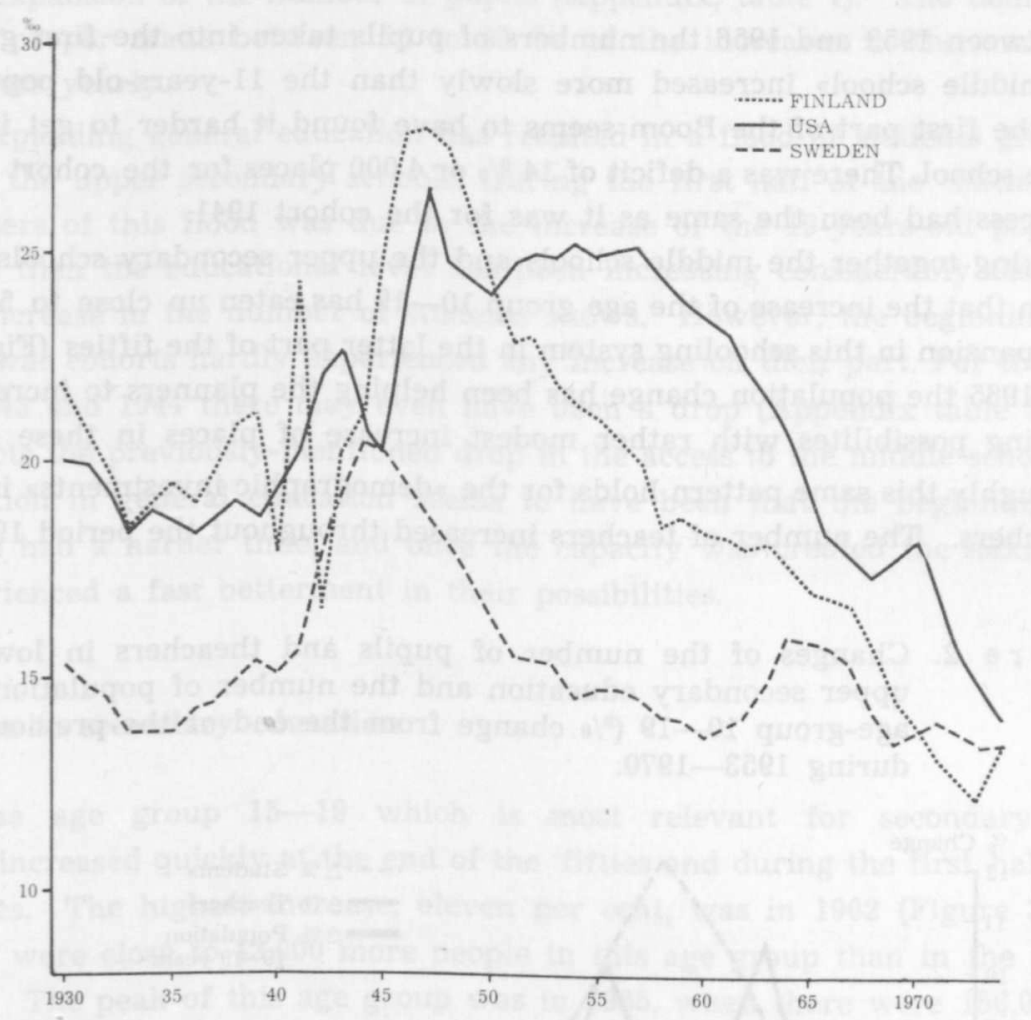

Sources: Historical Statistics of the USA

Statistical Abstracts of the USA, 1973, 1975

Finnish Statistical Yearbook 1975

Statistisk Årsbok för Sverige, 1953, 1964, 1974

school age ( $7-16$ years) increased in the fifties by $43 \%$, and has since declined by $17 \%$. The expanding "middle school» system has absorbed an increasing share of this population. In the 'fifties the number of pupils in primary schools $^{3}$ thus rose less, by $29 \%$. The increase was fastest in the mid-fifties, $4-5 \%$ a year. The investments in the primary school sector in forms of teacher did not between 1953-57 rise fast enough to meet the increase in numbers of pupils and the pupil/teacher ratio increased (Appendix table 1). There was also the problem of the education of teachers lagging behind the demand and in $195416 \%$ of the teachers in the rural areas were still unqualified.

3 The term »primary schools» refers here to the ordinary compulsory four first grades and the grades V-VIII in lower secondary school. 
The lower and upper secondary schools 4

Between 1953 and 1956 the numbers of pupils taken into the first grade of the "middle school» increased more slowly than the 11-years-old population. Thus the first part of the Boom seems to have found it harder to get into the middle school. There was a deficit of $14 \%$ or 4000 places for the cohort 1946 if the access had been the same as it was for the cohort 1941.

Taking together the middle schools and the upper secondary schools, it can be seen that the increase of the age group 10-19 has eaten up close to $50 \%$ of the expansion in this schooling system in the latter part of the fifties (Figure 2). Since 1965 the population change has been helping the planners to increase the schooling possibilites with rather modest increase of places in these schools.

Roughly this same pattern holds for the »demographic investments» in terms of teachers. The number of teachers increased throughout the period 1953-69.

Figure 2. Changes of the number of pupils and theachers in lower and upper secondary education and the number of population in the age-group 10-19 ( $\%$ change from the end of the previous year) during $1953-1970$.

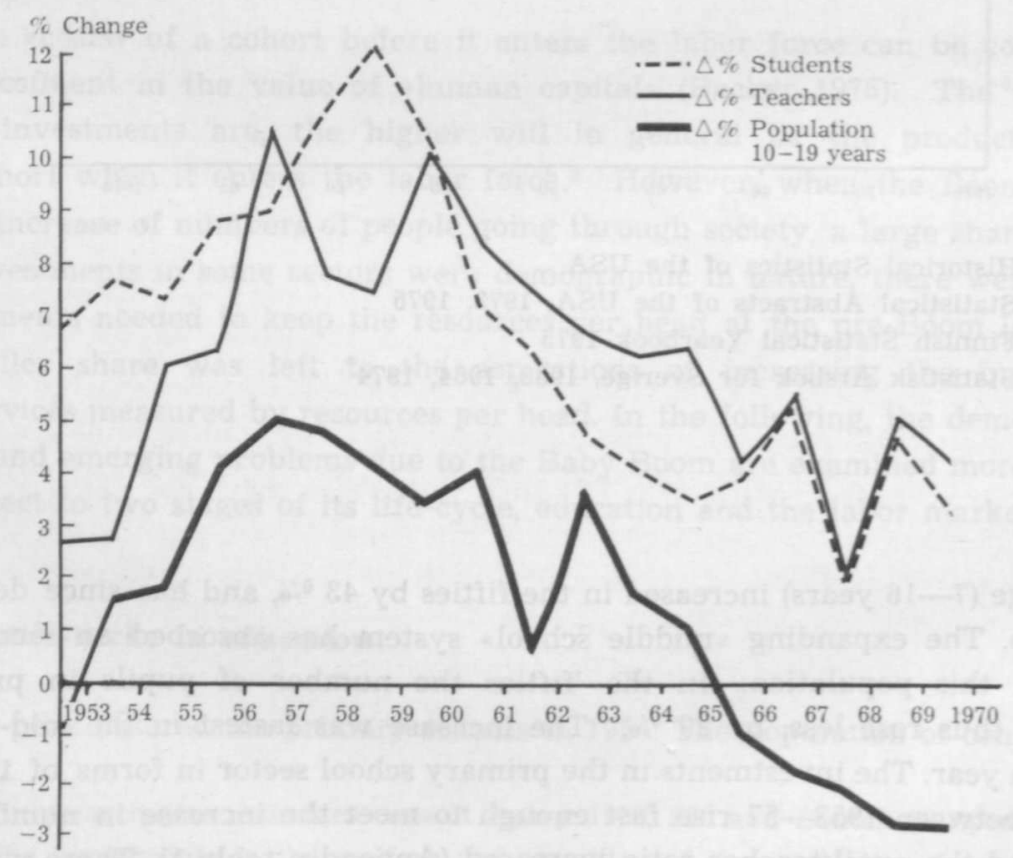

4 In Finland the lower secondary school has been divided in two systems, the first one consisting of the primary school and the smiddle school», the second and newer one consisting of a compulsory lower and higher stage. Both of the school systems lead to the upper secondary school and after that to higher education. In the 'seventies' this dual system was abolished by school reform. 
However, at the end of the 1950 s the pupil/teacher ratio increased, due to the fast expansion of the number of pupils (Appendix, table 1). The demographic need proper made between 50 to $65 \%$ of the increases in the numbers of teachers yearly.

Expanding general education has resulted in a flood of students graduating from the upper secondary schools. During the first half of the 'sixties, threequarters of this flood was due to the increase of the 19-years-old population. Since then the educational level has been increasing considerably faster than the increase in the number of students shows. However, the beginning of the post-war cohorts hardly experienced any increase on their part. For those born in 1943 and 1944 there may even have been a drop (Appendix table 2). ${ }^{5}$ This reflects the previously-mentioned drop in the access to the middle schools. The situation in general education seems to have been that the beginning of the Boom had a harder time, and once the capacity was created the next cohorts experienced a fast betterment in their possibilities.

\section{Access to secondary education}

The age group 15-19 which is most relevant for secondary education, increased quickly at the end of the 'fifties and during the first half of the 'sixties. The highest increase, eleven per cent, was in 1962 (Figure 3), when there were close to 43,000 more people in this age group than in the previous year. The peak of this age group was in 1965, when there were 156,000 more people between 15-19 than ten years earlier, an increase of $48 \%$.

The expanding general secondary education, increased throughout the period faster than the relevant age group and thus absorbed an increasing share of the population between 15 and 19 years. The population change accounted for only onequarter of the increase in the general secondary education. However, in terms of numbers there were 40 per cent more people outside the upper secondary schools than ten years earlier.

The access to upper secondary school seems to have got harder when the Boom started to enter. In 1959 the proportion of leavers from the middle schools started increasing. When the bulk of the cohort 1948 entered upper secondary school in 1964, the proportion of leavers was ten per cent higher than in 1960.

5 With the available data it is hard to say if this drop was »real» or not. The bottlenecks which the Boom faced may have resulted in kinds of "piling up" effects; when the resources are scare, people try to apply later. In this case, calculating the resources to the population of a certain age will give a slightly exaggered picture of the bottlenecks and also the betterment of the possibilities of the next cohorts. Thus the effects of the Boom may not have been as sharp as described here, but they have been longer. This problem has to be borne in mind when interpreting the results. 
Figure 3. The change in the number of pupils in all secondary education and the change in the population aged $15-19(\%$ change from the previous year) during $1954-1970$.

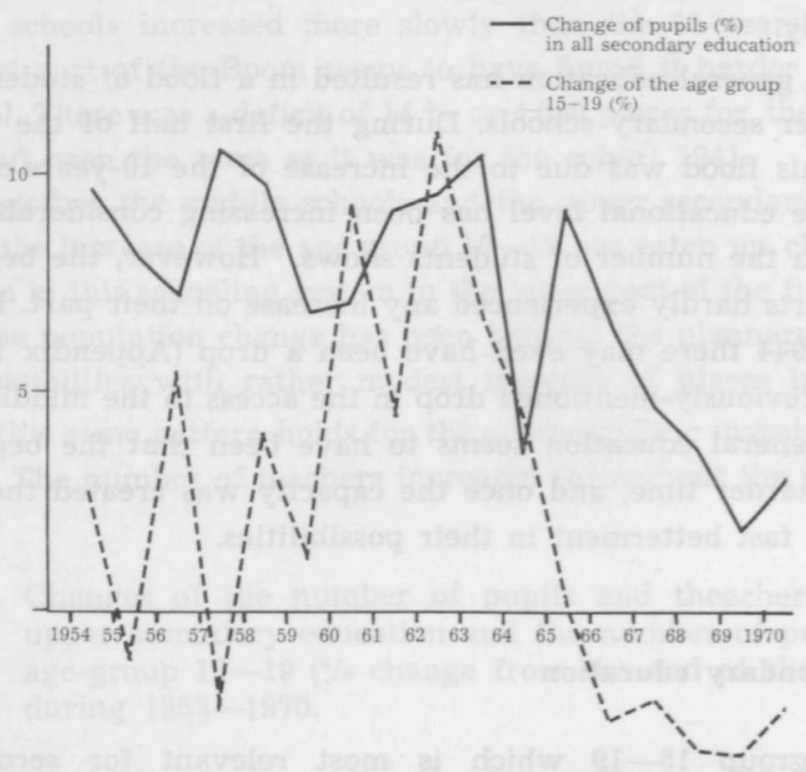

The number of leavers was 17,000, 2.5 times more than in 1960. Adding to these numbers those who finished the continuation of the primary school, there were some 75,000 new people competing for places in secondary vocational education in 1964 (Figure 4). Even though the number of new pupils taken into the vocational schools was increased exceptionally fast $(37 \%)$ at the beginning of the sixties, close to $80 \%$ of this increase was demographic in nature due to the increase of the population in the age group 15-19. The ratio of pupils taken into vocational schools to those leaving compulsory education was below $55 \%$ during 1960-63 (Appendix table 3). At the end of the sixties there were already more new places than people leaving compulsory education, due to demographic change and the expansion of general secondary education. However, an increasing share of the flood of students from upper secondary schools started to compete on the secondary vocational education market.

\section{Access to higher education}

The access of students to the universities became tighter throughout the 'sixties, but as far as the access of the cohorts is concerned the general trend has not been this dark. In Table 1 there are presented some indexes of the access to the universities. The ratio of new students at the universities to the 19-years-old cohort each year (column 3 ) shows that the ratio stayed practi- 
cally the same until 1969. Because the "potential population» applying to the universities does not consist only of 19-years-old people, because of reasons like the army and later entry to the schooling system, the older cohorts form a part of this potential population. In column (5) it is assumed that half of those who apply come from the 19-years-old cohort and the second half from those who are 20 years old. In column (6) the weights are calculated on the base of the autumn terms 1967 and 1968, assuming that the proportion taken in is the same regardless of the age of the applicant. According to this assumption, $42 \%$ "apply» when they are $19,32 \%$ when they are 20 and $24 \%$ at the age of $21 .{ }^{6}$

The Baby Boom seems to have had a hard time getting into the universities. The hardest time was for those who applied in 1968 when the first part of the Boom had filled up the universities. The decrease in sizes of the 19-years-old cohorts started already in 1966, but if the older entrants are taken into account, the decrease of the "potential» population did not start until 1968. The further tightening of the entry in 1968 was due to the restrictions upon the number

$\mathrm{T} a \mathrm{ble}$ 1. The ratio of new students at the universities to the relevant age group in $1959-72$

\begin{tabular}{|c|c|c|c|c|c|}
\hline $\begin{array}{l}\text { Change }(\%) \\
\text { in the num- } \\
\text { ber of new } \\
\text { entrants }\end{array}$ & $\begin{array}{l}\text { Ratio of } \\
\text { new en- } \\
\text { trants to } \\
\text { students } \\
(\%)\end{array}$ & $\begin{array}{c}\text { Ratio of } \\
\text { the new } \\
\text { entrants to } \\
\text { population } \\
\text { 19-years- } \\
\text { old cohort } \\
(\%)\end{array}$ & $\begin{array}{c}\text { mean of } \\
19 \text { and } 20 \\
\text { years-old } \\
\text { cohort }\end{array}$ & $\begin{array}{c}\text { weighted } \\
19-21 \\
\text { old pop. }\end{array}$ & $\begin{array}{c}\text { Change } \\
\text { the weig } \\
19-21 \\
\text { old po } \\
\text { lation } \\
\text { from } \\
\text { vious } y\end{array}$ \\
\hline (1) & (2) & (3) & (4) & (5) & (6) \\
\hline 4.2 & 84.0 & 9.8 & .. & 8.6 & \\
\hline 10.1 & 81.1 & 7.6 & 8.9 & 8.5 & 11.2 \\
\hline 1.5 & 75.0 & 11.3 & 9.2 & 9.4 & -8.1 \\
\hline 5.8 & 69.3 & 9.6 & 10.6 & 9.5 & 4.4 \\
\hline 19.4 & 79.2 & 10.6 & 11.3 & 10.9 & 4.6 \\
\hline 11.3 & 76.5 & 9.8 & 11.1 & 11.0 & 10.4 \\
\hline 16.5 & 76.8 & 10.5 & 11.2 & 12.1 & 6.0 \\
\hline 0.9 & 73.2 & 10.9 & 11.0 & 10.9 & 14.9 \\
\hline-1.6 & 66.6 & 10.8 & 10.9 & 10.5 & 1.7 \\
\hline-3.3 & 61.6 & 10.9 & 10.7 & 10.3 & -1.8 \\
\hline 9.6 & 64.2 & 19.5 & 12.4 & 11.8 & -4.5 \\
\hline-8.5 & 55.8 & 12.1 & 12.1 & 11.5 & -5.3 \\
\hline 4.9 & 53.8 & 12.4 & 12.6 & 12.1 & -0.1 \\
\hline 1.7 & 51.0 & 13.1 & 12.8 & 12.4 & -1.0 \\
\hline
\end{tabular}

Sources: Statistical yearbooks, SVT VI and corrected population estimates in the ' 60 's.

6 This calculation still neglects the possibility that the tight market has resulted in postponement of entry; i.e. the weights tend to increase for the older cohorts during a bottleneck and the »piling up» effects last still longer. Also the new students who were older than 21 have been left out of the calculation. 
$\mathrm{Figure}$ 4. The number of population leaving the compulsory education in 1953-70 and the rate of dropouts from the middle schools in 1953-70.

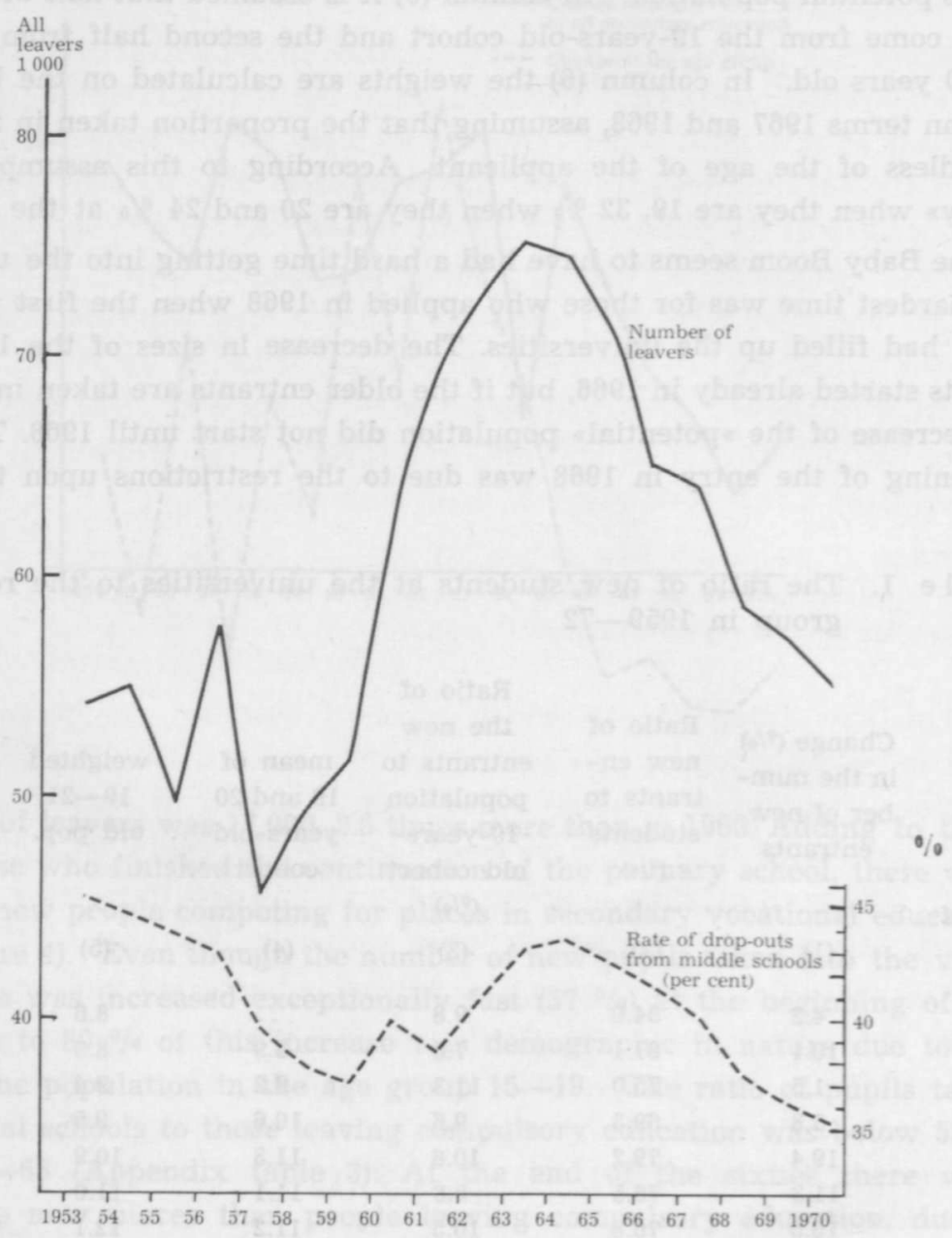

of new students taken into the universities. In Table 2 there is an attempt to follow some cohorts with the scarce data which is available. It shows the same kinds of results which can be inferred indirectly from Table 1. At the age 21 there has been a smaller proportion of the end of the Baby Boom at the universities than of the peak. The behaviour of the cohort 1950 may be due to the fact that in 1969, when the bulk of this cohort entered, the possibilities were better than for the cohort 1949 »cheap». But in 1970, when there still was about one-third of the cohort 1950 applying, they had a tighter market due to the drop in the numbers taken in. 
$\mathrm{Table} 2$. The proportion of students at the universities of some cohorts $(\%)$ at the ages $19-22$

Age

$\begin{array}{lcr} & 1945 & 1946 \\ 19 & \ldots 1 & \ldots \\ 20 & \ldots & \ldots \\ 21 & \ldots & 7.95 \\ 22 & 8.22 & 8.38 \\ & \\ \text { 1. data not available } \\ \text { Source: SVT XXXVII: } & 1-5\end{array}$

Source: SVT XXXVII: $1-5$

Cohort born in

1947

..

6.40

7.74

8.41

\section{8}

3.74

5.78

7.62

8.26
1949

3.45

5.67

7.19
1950

3.61

5.62
1951

3.97

.

Also in higher education there was a substitution of lower level teachers for professors at the beginning of the Boom. Moreover, there occurred marked increases in scheap" fields e.g. the humanities and the social sciences.

So we can conclude that the demographic investment needs due to the Boom ate up a large share of the fast expansion of the schools. In the beginning of the Boom the demographic needs were hardly even met. The financing of the Boom was partly done also by lowering the quality of education. Moreover the adjustments, especially in the vocational education sector, accured in a rather haphazard way: the flood spilled over wherever the fence was lowest.

\section{The problems of the Boom in the labor market}

The increase in the population of working age (WAP) has been mainly due to the effects of the Boom on the age structure. The increase was highest both in terms of numbers and in proportional terms in 1962 (Figure 5). In the latter part of the 1960's, emigration strongly diminished increase of the WAP. In 1969 there was even a drop in the population between 15 and 64 years of age. At the beginning of the 'seventies the net return migration raised the real changes over the natural change. ${ }^{7}$ The other effect of the Boom was that the structure of population of working age became younger (Table 3 ). The fast increase in the share of the 15-19-years-old population started during the second half of the 'fifties (see Figure 3). However, the age group 15-24, which comprises the bulk of the new entrants to the labor force, did not reach its peak until 1968, when there were $30 \%$ more people in this age group than in 1960 .

In Figure 6 there is tentative estimate of the proportion of the age group 15-19 who were outside the schools. Even thought the proportion in schools had been increasing - despite the bottleneck at the beginning of the 'sixties - the number of people outside the schools continued to increase until

7 See the article by Pekka Myrskylä in this volume (pp. $74-82$ ). 
$\mathrm{Table} 3$. The structure of and changes in the working age population in 1950,1960 and 1970

\begin{tabular}{lrrrrrrrr}
$\begin{array}{l}\text { Age } \\
\text { group }\end{array}$ & \multicolumn{2}{c}{$\begin{array}{c}1950 \\
\text { Thousands }\end{array} \%$} & Change & \multicolumn{2}{c}{$\begin{array}{c}1960 \\
\text { Thousands } \%\end{array}$} & Change & \multicolumn{2}{c}{1970} \\
Thousands & $\%$
\end{tabular}

Figure 5. Change in the population of working age (15-64) in 1957-74 (absolute change in thousands during the year).

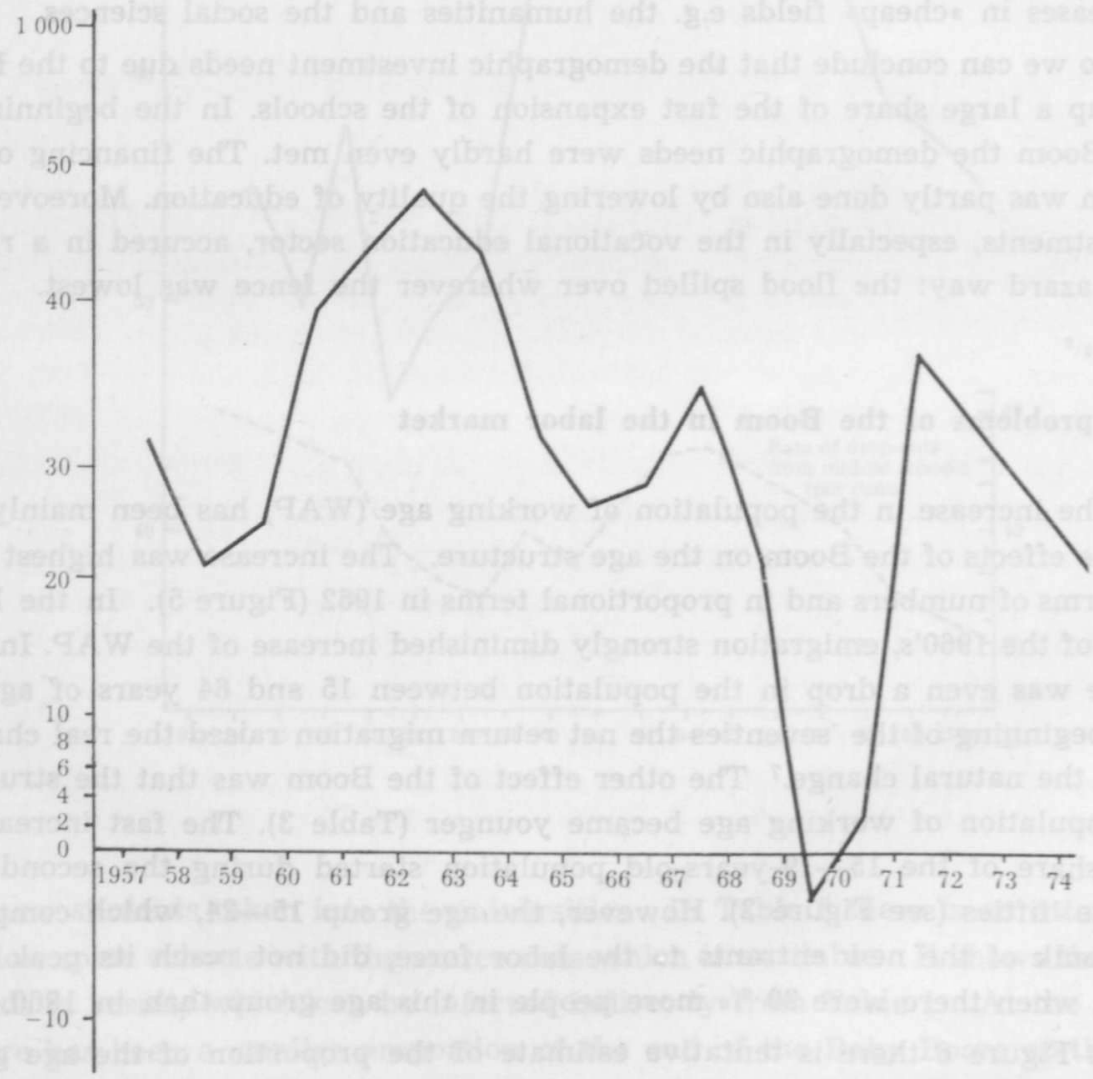

1965. In the years $1963-65$ there were around 300,000 people outside the schools in this age group. Because of the tight schooling market, there were a large number of young people who were forced to enter the labor market 
Figure 6. The 15-19 years old population by activity $(\% / 0)$ in $1960-70^{\text {a }}$.

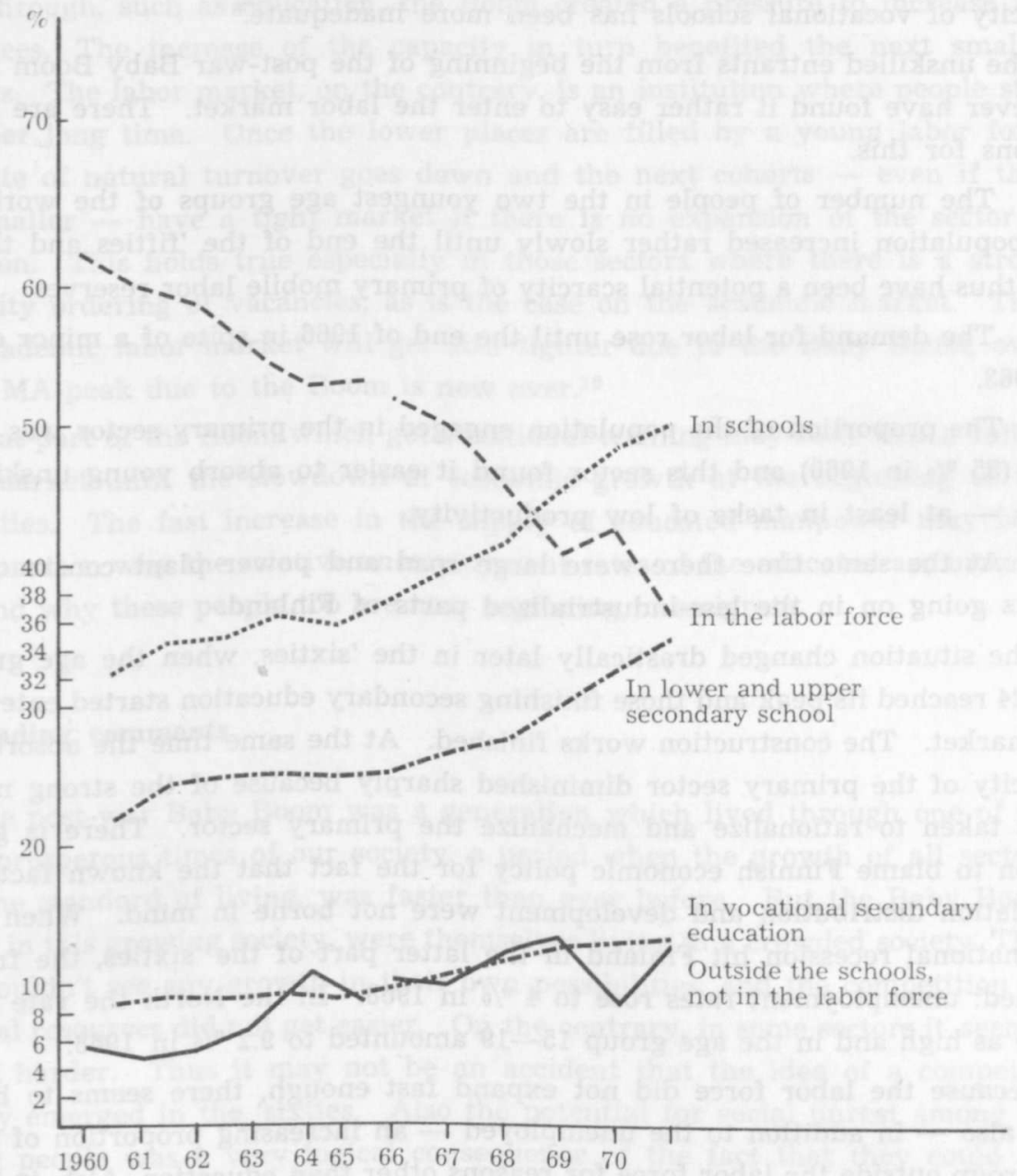

a The population outside the schools is a residual category which includes the home workers, disabled and those in the army and also those few people who were still in primary schools. The estimates of the labor force are based in $1965-70$ on the corrected labor force survey (Tilastotiedotus TY 1973:21 and 1976:3), fourth quarter, and before 1965 on the uncorrected average participation rates of the age group. The population in the lower and upper secondary schools is based on SVT IX. The proportion 15-19 in the vocational schools has been interpolated from the survey of Niini and Elfengren (1962) to the age structure survey in 1967 (Tilastotiedotus KO 1970:2). Thus the estimates for the first part of the 'sixties are rather uncertain.

without adequate vocational training. Even though they may have tried to catch up by applying to vocational schools later, there has emerged a problem of young unskilled labor expecially in those parts of the country where 
the natural increase of the population had been high, and where also the capacity of vocational schools has been more inadequate. ${ }^{8}$

The unskilled entrants from the beginning of the post-war Baby Boom may however have found it rather easy to enter the labor market. There are four reasons for this.

1. The number of people in the two youngest age groups of the working age population increased rather slowly until the end of the 'fifties and there may thus have been a potential scarcity of primary mobile labor reserves.

2. The demand for labor rose until the end of 1966 in spite of a minor drop in 1963.

3. The proportion of the population engaged in the primary sector was still high (35\% in 1960) and this sector found it easier to absorb young unskilled labor - at least in tasks of low productivity.

4. At the same time there were large road and power plant construction works going on in the less-industrialized parts of Finland.

The situation changed drastically later in the 'sixties, when the age group 15-24 reached its peak and those finishing secondary education started entering the market. The construction works finished. At the same time the absorbing capacity of the primary sector diminished sharply because of the strong measures taken to rationalize and mechanize the primary sector. There is good reason to blame Finnish economic policy for the fact that the known facts of population distribution and development were not borne in mind. When the international recession hit Finland in the latter part of the 'sixties, the fruits ripened: unemployment rates rose to $4 \%$ in 1968 . In the North the rate was twice as high and in the age group 15-19 amounted to $9.2 \%$ in 1968 .

Because the labor force did not expand fast enough, there seems to have been also - in addition to the unemployed - an increasing proportion of this age group outside the labor force for reasons other than education. Also, in this respect, the total figures for the country are just the top of an iceberg. This population pressure was perhaps a major factor behind the high outmigration rates in the rural areas. One outlet for this pressure was provided at the end of the 'sixties when the demand for labor in Sweden started to recover. In 1969 the population of working age even declined due to emigration. ${ }^{9}$

The relative unemployment rates of the young people have been increasing

8 According to estimates made in 1962 , the capacity of the vocational schools covered only $6 \%$ of the population of the age group $15-19$ in the Northern and Eastern parts of Finland, while the proportion in the South-Western urban centres was $17 \%$. (Niini \& Elfengren, 1962).

9 The situation was almost the same at the beginning of the century, when the phase of »transitional growth increased the population pressure. Then it resulted in the famous »America fever». 
rapidly even after the Boom. In those societal institutions which people just pass through, such as education, the Boom created a pressure to increase the resources. The increase of the capacity in turn benefited the next smaller cohorts. The labor market, on the contrary, is an institution where people stay a rather long time. Once the lower places are filled by a young labor force the rate of natural turnover goes down and the next cohorts - even if they are smaller - have a tight market if there is no expansion of the sector in question. This holds true especially in those sectors where there is a strong seniority ordering of vacancies, as is the case on the academic market. Thus the academic labor market will get still tighter due to the Baby Boom, even if the MA-peak due to the Boom is now over. ${ }^{10}$

That part of the Boom which got vocational training may have had a rather easy market until the slowdown of economic growth at the beginning of the 'seventies. The fast increase in the supply of educated manpower may be a strong reason why the relative unemployment rates of the educated are increasing, and why these people too are now beginning to emigrate.

\section{Concluding comments}

The post-war Baby Boom was a generation which lived through one of the most prosperous times of our society, a period when the growth of all sectors, and the standard of living, was faster than ever before. But the Baby Boom, living in this growing society, were themselves living in a crowded society. They just couldn't see any growth in their own possibilities, and the competition for societal resources did not get easier. On the contrary, in some sectors it seemed to get harder. Thus it may not be an accident that the idea of a competing society emerged in the 'sixties. Also the potential for social unrest among the young people was a very logical consequence of the fact that they could not see that the "Affluent Society» had given them anything more than before in respect to those needs which were most relevant in that stage of their life cycle.

The hard competition for education, work and housing may have been one strong factor explaining the heavy outmigration of the Boom cohorts. The factors behind the fact that the Boom has not produced an echo-effect in Finland may also be found from the bottleneck effects, which were caused by the exceptionally fast increase of people trying to enter different societal institutions. Because a baby in an industrialized society decreases the possibilities for upward and for regional mobility, one hypothesis could be that the nowadult Boom has directed investments into social mobility instead of reproduc-

10 The average age of getting an MA has been 27 years; $50 \%$ are between 25 and 29. For post-graduate degrees the corresponding figures are: the mean 34, first quartile 29 years, third 28 years (SVT VI C: 104, VII A). 
tion. In order to achieve a »proper» position in society, they have substituted, for example, longer education for babies; because there was a high »demand inflation" in the housing market, it was also "reasonable» to have an apartment now and children later. And just the fact that the children are postponed will lead usually to a lower completed fertility. It remains to be seen if the post-war Baby Boom will catch up later also in this respect, as did the cohorts $1915-20.11$

In general, the changes in the population pressure on the available resources may be a fruitful point of departure in examining many of the phenomena in society - historical, economic, and even cultural, just to mention a few of the fields where more investigation on the impact of population change is needed.

A ppendix table 1. Ratio of school pupils to population aged 15-19 and the pupil/teacher ratio.

Middle schools and upper secondary schools

\begin{tabular}{|c|c|c|c|c|c|c|}
\hline $\begin{array}{l}\text { End of } \\
\text { year }\end{array}$ & $\begin{array}{c}\text { Pupils per } \\
\text { population } \\
15-19 \\
(\%)\end{array}$ & $\begin{array}{c}\text { Change } \\
\%\end{array}$ & $\begin{array}{c}\text { Average } \\
\text { size of } \\
\text { class }\end{array}$ & $\begin{array}{c}\text { To all } \\
\text { teachers }\end{array}$ & $\begin{array}{l}\text { cher ratio } \\
\text { To full- } \\
\text { time } \\
\text { teachers }\end{array}$ & $\begin{array}{c}\text { Primary } \\
\text { Schools } \\
\text { Pupil/teacher } \\
\text { ratio }\end{array}$ \\
\hline 1950 & 14.8 & $\ldots$ & $\ldots$ & 17.1 & $\ldots$ & 23.2 \\
\hline 1951 & 15.2 & 2.7 & $\ldots$ & 17.3 & .. & 23.2 \\
\hline 1952 & 16.6 & 9.3 & 31.3 & 18.0 & 35 & 23.8 \\
\hline 1953 & 17.4 & 4.5 & 32.3 & 18.9 & 37 & 24.2 \\
\hline 1954 & 18.3 & 5.4 & 32.5 & 19.1 & 39 & 24.4 \\
\hline 1955 & 19.1 & 4.4 & 33.1 & 19.5 & 40 & 24.4 \\
\hline 1956 & 19.9 & 3.8 & 33.2 & 19.3 & 43 & 24.5 \\
\hline 1957 & 20.1 & 1.2 & 33.7 & 19.8 & 41 & 24.7 \\
\hline 1958 & 22.6 & 12.3 & 35.2 & 20.7 & 41 & 23.9 \\
\hline 1959 & 24.1 & 6.7 & 34.5 & 20.7 & 39 & 23.4 \\
\hline 1960 & 24.9 & 3.2 & 34.3 & 20.5 & 38 & 22.9 \\
\hline 1961 & 26.3 & 5.6 & 34.3 & 20.4 & 37 & 22.4 \\
\hline 1962 & 26.6 & 1.1 & 34.2 & 20.0 & 36 & 21.9 \\
\hline 1963 & 27.2 & 2.3 & 33.9 & 19.6 & 34 & 21.8 \\
\hline 1964 & 28.0 & 2.2 & 33.4 & 19.1 & 33 & 21.3 \\
\hline 1965 & 29.2 & 5.1 & 33.6 & 19.0 & 32 & 21.0 \\
\hline 1966 & 31.3 & 7.1 & 33.6 & 18.9 & 32 & 20.5 \\
\hline 1967 & 33.0 & 5.5 & 33.5 & 18.9 & 31 & 20.5 \\
\hline 1968 & 35.6 & 7.8 & 33.0 & 18.7 & 31 & 20.3 \\
\hline 1969 & 37.7 & 6.0 & 33.0 & 18.5 & 30 & $\ldots$ \\
\hline
\end{tabular}

Sources: SVT IX and $\mathrm{X}$.

11 See the article by Gunnar Fougstedt in this volume (pp. 41-66). 
A p pendix table 2. The ratio of students graduating from upper secondary schools to 19-years-old population

$\begin{array}{cccc} & & \text { Ratio of } & 19 \text {-years-old } \\ \text { Midyear } & \text { Change from previous year }(\%) & \text { Students to } & \text { students } \% \text { of } \\ & \begin{array}{c}\text { of } 19 \text {-years- } \\ \text { old cohort of students }\end{array} & 19 \text {-years-old } & 19 \text {-years-old } \\ & \text { cohort }(\%) & \text { population }\end{array}$

(2)

(3)

(4)

$\begin{array}{lrrrr}1959 & -15.3 & 8.6 & 11.7 & \ldots \\ 1960 & 40.7 & 14.2 & 9.4 & \ldots \\ 1961 & -30.4 & 9.7 & 14.8 & 5.5 \\ 1962 & 22.4 & 14.4 & 13.9 & 5.1 \\ 1963 & 8.5 & 4.5 & 13.4 & 5.1 \\ 1964 & 18.2 & 15.2 & 13.0 & 5.2 \\ 1965 & 10.5 & 16.0 & 13.7 & 5.7 * \\ 1966 & -0.7 & 8.5 & 14.9 & 5.7 \\ 1967 & -0.1 & 8.3 & 16.2 & 6.0^{*} \\ 1968 & -4.0 & 4.4 & 17.6 & 6.1 \\ 1969 & -4.3 & 5.2 & 19.4 & 6.8 * \\ 1970 & -5.9 & 5.3 & 21.6 & 7.5 \\ 1971 & 2.3 & 8.8 & 23.1 & 8.9 \\ 1972 & -3.4 & 7.4 & 25.6 & 10.6 * \\ 1973 & 0.6 & 7.2 & 27.3 & \ldots\end{array}$

Source SVT IX.

* Estimates based on the age distribution of the seventh grade in the previous year.

A p pendix table 3. Ratio of places in secondary education to population in $1959-70$

Change from previous year $(\%)$ of

\begin{tabular}{|c|c|c|c|c|c|c|c|}
\hline $\begin{array}{l}\text { Autumn } \\
\text { term }\end{array}$ & 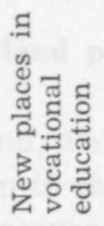 & 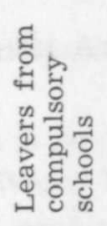 & 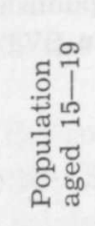 & 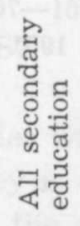 & 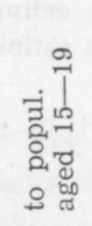 & 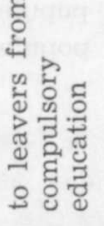 & 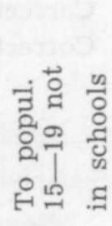 \\
\hline 1959 & 5.8 & 8.7 & 1.1 & 6.8 & 8.7 & 59.4 & . \\
\hline 60 & 6.6 & 6.4 & 9.3 & 7.0 & 8.5 & 59.4 & 11.0 \\
\hline 61 & 8.8 & 19.5 & 4.6 & 9.2 & 8.8 & 54.0 & 11.8 \\
\hline 62 & 14.1 & 13.4 & 11.0 & 9.5 & 9.1 & 54.4 & 12.1 \\
\hline 63 & 5.2 & 4.8 & 6.8 & 10.4 & 8.9 & 54.5 & 12.1 \\
\hline 64 & 4.8 & 1.6 & 4.5 & 3.5 & 9.0 & 56.3 & 12.0 \\
\hline 65 & 9.0 & -2.1 & 0.0 & 9.2 & 9.8 & 66.2 & 13.2 \\
\hline 66 & 7.9 & -5.1 & -2.5 & 6.5 & 10.8 & 71.8 & $1+.9$ \\
\hline 67 & 6.8 & -5.4 & -2.0 & 4.7 & 11.8 & 81.0 & 16.4 \\
\hline 68 & 2.5 & -5.4 & -3.2 & 3.8 & 12.4 & 87.8 & 18.1 \\
\hline 69 & 1.4 & -6.8 & -3.3 & 1.9 & 13.1 & 95.6 & 19.7 \\
\hline 1970 & 1.4 & -4.6 & -2.3 & 3.1 & 13.6 & 101.5 & 21.0 \\
\hline
\end{tabular}

New places in vocational schools

Sources: Sauvala 1972 and Statistical yearbooks. 


\section{References}

Becker, G. S., »Human Capital», NBER, New York 1975

Coale, A. J. and Hoover, E. M., »Population Growth and Economic Development in Low Income Countries», Princeton 1958

Denton, F. T. and Spencer B. G., »Population and the Economy», Saxon House 1975

Easterlin R. A., "Population Labor Force and Long Swings in Economic Growth», NBER, New York 1968

Niini A. and Elfengren E., "Nuorten koulunkäyntimahdollisuudet ja työmarkkinoille tulo 1955-65" Valtak. suunn. tsto A: 12, Helsinki 1962

»Population Policies and Economic Development», World Bank Staff Report 1974

Sauvala, A., "Keskiasteen koulutus Suomessa 1918-1980», Dept of Education, Univ. of Jyväskylä, Research Reports 37, 1972

Sauvy, A., »General Theory of Population», London 1966

\section{Sources of statistical data}

»Historical Statistics of the USA, Colonial Times to 1970 », Bureau of Census, Washington 1976

Statistical Abstracts for the USA

Statistical yearbooks of Finland

Statistisk Årsbok för Sverige

SVT VI A Väestömuutokset

SVT VI C Väestölaskenta

SVT IX Oppikoulut

SVT X Kansanopetus

SVT XXXVII Korkeakoulut

\section{Tilastotiedotus:}

KO 1970: 3 »Oppilaiden ikärakenne keskiasteen koulutuksessa syksyllä 1967»

TY 1973:21 »Työvoimatiedustelun korjatut tulokset 1970 ja -71 »

TY 1976:3 "Työvoimatiedustelun korjatut tulokset 1965-69"

Corrected population estimates $1961-70$ (unpublished)

Corrected population estimates in 1951-60 in SVT VI: A 128 